\title{
sciendo
}

\author{
BOŻENA PŁONKA-SYROKA
}

\section{Medical doctrines at the turn of the 18th and 19th c. and their philosophical foundations}

\begin{abstract}
The turn of the 18th and 19th c. is a period in the history of medicine where the division of the main modernisation course in clinical medicine was made. Two competing movements were distinguished at that time: physical, the foundations of which referred to the philosophy of the English and French Enlightenment (the so-called Medical Enlightenment) and romantic, which was critical of the philosophy and attempted to base the foundations of medicine on German idealism. The rivalry began in 1797 when the basis of the romantic movement was determined and ended in 1849 when the movement was removed through administrative channels from universities in German Protestant states. Then, the unification of the theoretical foundations of clinical medicine in Europe took place, while the epigones of the romantic movement were included in the area of alternative medicine by academic communities. Both of the movements involved dozens of medical doctrines, which strove to solve practical therapeutic problems in relation to different theories. The aim of the article is to present the rivalry between both modernisation movements on the basis of my earlier studies, the results of which were included in the publications from 1990-2016, and references with particular emphasis on the role of therapeutic doctrines and their philosophical foundations.
\end{abstract}

Keywords: medical theories and doctrines, medicine at the turn of the 18th and 19th c.

DOI: $10.2478 /$ pjph-2018-0007

\section{Presentation of the basic concepts}

Firstly, the analysis of the issue requires the clarification of the basic concepts that will be used in the article because the concept of medical doctrines is defined in a different way in the papers of eminent classic authors of Polish medicine historiography. Ludwik Zembrzuski [1] recognises doctrines as a practical expression of the medical theory, which belongs to their certain group and creates a theoretical course combined. This way of defining is concurrent with the one present in legal terminology. Władysław Szumowski [2] has a different approach to the issue. He defines doctrines in plain language as a simplified and generally incorrect concept, which is popularised by medical practitioners with poor scientific knowledge, who are eager to achieve an immediate success and referred to as doctrinaires - or sectarians in extreme cases. As the Szumowski's textbook, whose first edition was published in 1935, is still renewed and in use in Poland as an academic textbook, Polish authors who do not accept Szumowski's definition of doctrines in the book have to indicate and present their own suggestions concerning exploring the issues of the genesis and reception of medical doctrines in the medical European world at the turn of the 18th and 19th c. therefore suggested the methods for defining medical theories and doctrines and their interactions [3]. I made use of these definitions in further research on the modernisation process of clinical medicine [4]. The medical theory is defined as a broad hypothesis that determines the direction and scope of research, the priorities of which are set by the hypothesis, and that determines the areas forbidden to be researched scientifically (that is those the actual significance of which cannot be proven according to a given theory) and refers to a certain philosophical concept from which general assumptions, metaphysics and methodology are taken. The medical theory addresses a resource of experience elements of the epoch in which it is formulated. It covers part of the resource and puts it in order in a characteristic way. It has an open structure, i.e. may be expanded in a particular direction along with the increase in scientific knowledge as compared to its amount when it is formulated [5]. The medical doctrine is defined as a practical and operational conceptualisation that combines a general vision on the philosophy of nature, method and scope of scientific cognition with specific solutions from the field of pathology, physiology, diagnostic, and therapy [4]. I treat it as a closed structure, i.e. it undergoes limited modifications. Therefore, the elimination of a medical doctrine from therapeutic practice is easier and faster than of a medical theory, on the basis of which a doctrine was formulated. Lack of expected effectiveness in a range defined by a given doctrine initiates attempts to modify its structure or specify its use applications. If they do not lead to positive results, the doctrine may be criticised. Initially, therapeutic failures associated with a practical application of the doctrine are marginalised or reflected as imminent; further, they are explained that they were caused by the improper application of the doctrine (rather than the doctrine being improper itself), and then they are explained that they are the result of the unpredictable occurrence of the limitation to its application. However, the final elimination of 
the doctrine from medical practice occurs after a medical environment authorities ruling on the issue. As the authorities belong to different medical schools, the criticism and elimination of the medical doctrine is asynchronous. Simultaneously, the reception of the same doctrine in various medical schools may take various forms: from full reception, through partial reception to blocked reception. The last one may be the result of the repression of the doctrine remains from medical practice or the blockage of its reception a priori, which never took place fully [6]. Numerous doctrines may be established on the basis of one medical theory. These doctrines compete against each other in terms of the effectiveness of their practical application. The elimination of subsequent doctrines based on the same medical theory from practice does not discredit the theory as such. It is possible to formulate new doctrines that are adapted to the movement development level of a given theory and will receive recognition from their supporters. A given medical theory is discredited and no further medical doctrines are established on its basis only when another medical theory and medical doctrines associated with it manage to solve the issues that the discredited medical theory could not solve, as well as when the new medical theory indicates issues (and solutions to them) that the previous medical theory did not find [7].

The medical doctrine is a concept that has a characteristic structure [8]. Three levels of the medical doctrine, which vary in the degree of generality as well as in their relationship to medical practice, may be distinguished. The first level, i.e. constitutive, is comprised of direct references to the medical theory a given doctrine was based on. This level also includes references to a specific philosophical movement that serves as the foundation of a given doctrine. The second level is nomothetic. Referring to the theoretical foundations described at the constitutive level, the author of the doctrine suggests its specific order. This level also determines the originality of the doctrine and lays the foundations of medical practice in accordance with its assumptions. The third level is variational. It involves specific diagnostic and therapeutic recommendations resulting from the assumptions of a given doctrine, but also a set of medication that the doctrine's author considers to be effective and compliant with its assumptions. As far as conventional European medicine is concerned, medical doctrines competed against each other on the basis of their effectiveness assessment in particular. However, if the constitutive and nomothetic levels of a given doctrine could not be adopted (for various reasons) outside the medical school where the doctrine was formulated and its variational level affirmed their application effectiveness, representatives of other medical schools attempted to clarify its effectiveness by referring to the assumptions of their own school. Therefore, clinical experience was subject to interpretations based on different theoretical foundations, which determined the dynamics of the modernisation process [9].

A characteristic sequence of medical theories was reflected in conventional European medicine at the turn of the 18th and 19th c. The sequence was related to the approval of its assumptions and basic principles by various medical schools [7]. The principles were associated with a representative approach to a problematic situation that theories tried to solve. In this case, the concept of an objective problematic situation, i.e. a set of all research questions that may be asked and answers to them that can be provided in a given historical period according to the level of knowledge and technology at the time, and a subjective problematic situation, i.e. a set of research questions targeted according to the assumptions of a given scientific theory and possible to be asked within its boundaries with answers that do not exceed these boundaries, is distinguished. The authors of theories that competed against each other formed disproportionate conceptualisations, which were the solution to problematic situations created in the area of their cognitive perspectives in question. Medical theories derived therapeutic doctrines, which competed against each other in terms of application effectiveness, which contributed to lending credence to or gradually discrediting the theory the doctrines were associated with. As a result, the scope of the reception of a given medical doctrine was determined by what practical problems it could solve, whether those problems were regarded as relevant and requiring solutions by physicians, and what methods would be used to solve those problems. Each of those issues required the adoption of a given theoretical approach, which would imply the epistemological foundations of medicine and the research methodology recognized in a given medical school as rational. Supporters of different theories varied not only in terms of experience interpretation, but also in terms of what scope of experience might be defined as existing in reality. For that reason, medical theories and doctrines were disproportionate both in observing and interpreting terms until one of them gained an advantage and was widely received [4].

In the 16th c. European medicine saw a crisis in theories, which the medical community endeavoured to solve through the selection of a sequence of strategies. The crisis was sparked off by the codification of the level of knowledge represented by ancient authors and printing their beliefs. The transition from oral transmission and manuscripts to printed books made not only the propagation of the knowledge achieved by ancient authors possible but also gave rise to its criticism. Errors, inaccuracies and contradictions were found in their works and tried to be clarified. However, the process turned out to be much more long-lasting than the initiators in the Renaissance assumed. Seven consecutive strategies targeted at resolving the crisis, each of which with their supporters were adopted in the medical environment. The first one assumed that it is possible to modify the applicable normative theory (humoralism) through the inclusion of elements of other theories, which were based on the same problematic situation, in its structure. The second one considered it necessary to replace the applicable normative theory with another, already existent and built on the basis on the same problematic situation. The third one considered the first two strategies to be impossible and suggested establishing a new normative theory, which would refer to the same problematic situation as the criticised theory. The supporters of the fourth strategy regarded the first three strategies as not leading to the resolution of the crisis. They claimed that failure to develop effective therapeutic doctrines based on the theories formulated with a common problematic situation not only challenges the rationality of those theories, but also the rationality of the problematic situation to which the theories are to be the solution. They recommended granting the normative status to one of the theories advanced in relation to an earlier problematic situation than the one to which the criticized theories at that time were formulated as a response [4]. Between 1797 and 1848 the abovementioned strategies met with more and more criticism from clinical practitioners in the academic European world [10]. 
The essence of the dispute between them was an attempt to modify further the normative theory at that time (humoralism) through the inclusion of contemporary medical knowledge in it, or through lack of such attempts and striving for the formulation of a new normative theory and new doctrines associated with it in response to a new problematic situation. Until 1830 none of the positions could gain an advantage because all doctrines based on competing medical theories demonstrated little effectiveness. Representatives of various clinical schools took a different direction in that situation. Supporters of the above-mentioned first strategy gained an edge in most European countries. Building on a new methodology for clinical medicine, they wished to modify the normative theory at that time (humoralism) not only through the inclusion of new knowledge elements, but also through the elimination of elements that proved to be non-compliant with clinical experience from the theory and therapeutic doctrines associated with it. Since most of those doctrines were ineffective after research for seven decades (1750-1830), the supporters of that direction decided to limit their action focused on establishing a new system; instead, they decided to specify the scope of clinical observations which could be regarded as realistic as they were based on a proper methodology. That strategy (which I defined as the sixth) served as the basis for the seventh strategy, the foundations of which were to try to develop a new problematic situation of clinical medicine that a new normative theory would be the solution to. The action carried out in that direction was successful in the 1880s when the humoral system and physical and theoretical concepts established as its opposition (e.g. anathomopathological theory) were replaced with bacteriology. Solid methodological foundations were laid in the main modernisation movement of clinical medicine until 1850. They referred to moderate philosophical skepticism and made the change possible.

At the same time (1797-1848), a competitive modernisation movement of clinical medicine, which referred to German idealism in its philosophical foundations, emerged in German Lutheran countries [11]. Initially, its supporters stood for the replacement of humoralism with another concept dating back to ancient times (hermeticism), which was developed by Paracelsus and Van Helmont in the German medical tradition (that involved the adoption of the fourth and fifth strategy introduced by me). Then the supporters took action associated with the sixth and seventh strategy (limiting action focused on establishing a new system in favour of formulating new theories and therapeutic doctrines in relation to them). However, their method for formulating the new medicine system was inconsistent with the direction taken in the main movement of the clinical medicine reform, from which they drew theoretical and practical foundations [4].

\section{Theoretical foundations for the modernisation of clini- cal medicine (1750-1850)}

Between 1750 and 1850, a modern ideal of science was received in conventional European medicine [12]. Its premises determined the boundaries of science rationality, what concepts could be included in its field, what and with what methods problems might be solved. The ideal of modern science also determined what problems would not be scientific and what methods would not be employed by the academic world [12]. In the main movement of the clinical medicine reform, the reception of the modern science ideal formed the so-called Medical Enlightenment, which determined both the direction of clinical research and its methodology [13]. The essence of the new research foundation was scholars' trust in their own cognitive abilities [14]. That justified asking new research questions audaciously on the part of scholars and seeking answers to them that were rational to scholars themselves. Scholars who posed those questions made autonomous decisions on what elements of the medical knowledge system until then should be rendered obsolete. That could happen due to the fact that scholars regarded the old questions and the answers to them, which were part of the previous knowledge, as irrational, or due to the fact that answers to them were not seen as counterfactual according to the level of knowledge at that time (without undermining the significance of old questions that were considered worth posing). Granting themselves the right to take apart the elements of a fixed structure of the medical knowledge at that time, medical practitioners following the Medical Enlightenment were not motivated by voluntarism or epistemological anarchism. Criticising the socalled "thick empiricism", they attempted to establish a solid methodology for scientific research, based on facts and their reliable interpretation [10]. The reliability was to be provided by the foundation of a professional philosophy of medicine, which would enable medical practitioners to participate in scientific debates and consider such medical practitioners to be independent experts by both the authorities and the church [15], also by the necessity of publishing not only the results of experiments but also present the methods on which experiments were based, but most of all by the transparency of clinical procedures, which would be available at any of their stages to scholars interested and make possible through a careful provision of documentation. Medical records, hospital statistics, and a topology of catching a disease would lend credibility to the new system of medical knowledge; they would all be discussed comprehensively and in detail in specialist literature. They were to give the possibility to compile an actual list of the incidence of diseases, their treatment results and the range of their occurrence. According to the supporters of the Medical Enlightenment, modern clinical medicine was supposed to be the science based on clinical experience and its interpretation, suggested by individual scholars who had it assessed by the environment. It was to be a system with a fixed regulation mechanism built in its structure, which would enable doctrines associated with it to be currently assessed in terms of theoretical correctness and practical effectiveness. Clinicians of the main modernisation movement considered moderate philosophical skepticism to be the foundation of the professional philosophy of medicine [4]. That gave an opportunity for a gradual evolution of the system of the main modernisation movement, in which solid protective barriers were erected to separate professional academic discourse from concepts not to be discussed in the scientific world since they did not meet high methodological requirements and also established frameworks for the development of discussions in the discourse concerning both the theory and practice of medicine. The development of precise criteria for the evaluation of medical theories and doctrines resulted from a practical attitude of the main modernisation movement of clinical medicine. If a medical doctrine could be examined practically in the clinical environment, starting from 1784 it had to be based on the theory, the structure and methodology of which were considered to be rational by the authorities of the environment (national 
academies of sciences, faculties of medicine at acclaimed universities). The evaluation of a medical doctrine value concerned the therapeutic effectiveness of its application. If the effectiveness (in comparison to the doctrines already in use) was assessed negatively after a few or a dozen or so years, the new doctrine was usually removed from clinical practice [16]. However, if it proved to be more effective than those in use, there was an incentive to apply it further in clinical practice until a new and more effective method of therapy was developed. Conventional medicine, which was based on clinical facts, approved the fluency and fluidity of the new system and considered it to be a beneficial and inevitable phenomenon. In 1850 Claude Bernard specified precisely the principles of experimental medicine methodology [17]. Within only a quarter of a century, a new pathology system, which rendered all other norms obsolete, was introduced, namely bacteriology [18]. However, cognitive and practical effectiveness of the main modernisation movement of clinical medicine did not come from the so-called Medical Enlightenment system. It also came from shaping the mentality of the scientific European world by Aristotle's philosophy over the centuries [7]. Due to Aristotle's influence, the scientific European world featured an autoreferential ability, i.e. ability to gather experiences, on the basis of which assessments were made and action was modified. In this perspective, the variability of a medicine system did not lead to its destruction, but to the increase in the coherence of human knowledge (due to the elimination of misconceptions from it) and to the increase in its effectiveness (by building practice on effective concepts). The ability proved to be of particular usefulness when Aristotelian physics was replaced with Newtonian physics with the consent of the pope in the academic curriculum of European Catholic countries in 1757 [4]. In fact, it turned out that it was possible to divide Aristotelianism into several levels, remove those elements that were no longer approved by clinicians from it (a physical image of the world, teleological explanations), and simultaneously preserve those that were still considered to be inspiring (a two-valued logic, empirical knowledge model).

At the same time, the reception of the conceptual scheme, i.e. the Medical Enlightenment, was hindered due to theoretical and philosophical reasons in the German Lutheran culture [19]. The issue that local modernisers of a clinical system had to face was a considerate disparity in the epistemology generally accepted in the main European clinical movement, which was based on the foundations of moderate skepticism, as well as a different approach to the role of an individual personal and cognitive entity in Catholicism and Protestantism. It was a passive role, based on Saint Augustine, in Lutheranism [7], whereas in Catholicism it was an active role based on Aristotle and Saint Thomas. Therefore, there was a division, which was conditioned by the attitude to those fundamental theoretical issues, in the medical German world at the turn of the 18th and 19th c. Initially (between 1750-1830), the system of the Older Viennese School, with humoralism and the neo-hippocratic doctrine, had a major impact on German Lutheran physicians. The most notable representative of that school was Christoph Wilhelm Hufeland [20], a professor at the University of Berlin, who gave superiority to the aspects of a professional methodology of clinical medicine, along with its methodology based on moderate philosophical skepticism, over philosophical elements resulting from the Lutheran tradition [21]. The views of the scholar met with criticism leveled at many areas in the academic German world. The first criticism area was that the normative theory of the Older Viennese School was erroneous and the recommendation was to replace it with another, which would answer the problematic situation preceding the formulation of humoralism. The supporters of that view saw it necessary to refer to the traditions of ancient hermeticism, which were predominant in the scientific German environment in the Middle Ages and modern times, and to replace a model of a disease based on the four bodily fluids (humours) with a model based on the recognition of the dominant role of the spirit (anima) in the control of all life processes. The above-mentioned idea achieved a lot of recognition in the academic German world, and was supported by, among others, Carl Gustav Carus [11] and Karl Friedrich Burdach [22]. Another criticism area of the reception of the Older Viennese School system in conventional German medicine was a movement referring to the leading role of the nervous system in the control of life processes. That was a new discovery in clinical medicine, which, according to the supporters of the movement, discredited the system of humoralism because the discovery could not be included in the structure of humoralism in any way. The so-called nervous pathology was the normative theory of the movement, and its main therapeutic doctrine, which was formulated on the basis of the theory, was the John Brown's doctrine [23]. Although it was established outside Germany (in Scotland) as a simplified reinterpretation of the views of William Cullen, an experienced clinician, it was not given clear recognition in the academic European world, except for Germany. Brownism had a major impact on the medical German theory and practice both in the original form and its reinterpretations until 1830s [24]. The third criticism area was represented by physicians who claimed there was the necessity for the development of a new problematic situation of the German clinical medicine based on original philosophical foundations, which were different than those in the main European clinical movement. That involved the approval of a specific (only for Germany) concept of the physical image of the world [25], specific concept of epistemology [26], and the rejection of the concept of knowledge based on inductive reasoning. The proponents of that concept recommended building the medical theory on deductive reasoning from a priori statements that were considered to be certain. Therapeutic doctrines were compliant with that approach. For that reason, no procedures for the empirical verification of their effectiveness were included in their structure. Doctrines assumed their effectiveness in advance, and the fact that doctrines were based on appropriate theoretical foundations justified them. The supporters of the movement explained that therapeutic failures associated with the practical application of doctrines were the result of an incorrect application of doctrines that were compliant with their principles and well based in theoretical terms in the reality of surrounding nature. Lukas Schönlein was the most notable representative of the movement referred to as Naturphilosophische Medizin [27]. He attracted hundreds of supporters at German universities, including dozens who formulated new therapeutic doctrines.

In the German medical world in the 1830s and 1840s there were also people who advocated the consolidation of the German system of conventional medicine with the West Europe system. Criticising the three above-mentioned German modernisation movements, they followed the advances in clinical knowledge abroad and tried to apply it practically in Germany. 
That movement gathered many supporters among medical practitioners already in the 1840 s, who were primarily interested in the effectiveness of therapy rather than in a dogmatic adherence to the imponderables of a native clinical system. During the Spring of Nations (1848-1849), their position prevailed and met with the authorities' approval, who found an actual increase in the therapy effectiveness more appealing than the compliance of its theoretical foundation with the "appropriate" ideological foundation. As a result, the European medical system was received in the German conventional and practical medicine between 1849 and 1880. The same scientific problems were discussed under that system, while research results were achieved on the basis of the analysis of clinical specimens. The German medicine became especially effective and innovative because the academic world endeavored to catch up on what they lacked between 1797 and 1848 in terms of modernisation. The removal of an antimaterialistic theoretical system and doctrines associated with it from the German conventional medicine resulted from the ineffectiveness of suggested therapy methods in the first place. That was due to patients' objections (who did not wish to follow ineffective procedures) and physicians' (who did not wish to lose patients as they received treatment abroad i.e. where there was a different clinical system).

\section{III. "Old" therapeutic doctrine vs. "new" therapeutic doc- trines and their competition for the normative status}

At the turn of the 18th and 19th c. humoralism played the role of the normative theory in medicine faculties at the European universities [28]. Its practical expansion was the neo-hippocratism doctrine, which was developed by Thomas Sydenham in the 17th c. [29] and modified by Herman Boerhaave in the 18th c. [30]. Within the next two centuries, the doctrine underwent further modifications that did not affect its practical orientation and reliance on empirical facts [31]. However, the number of modifications over time led to the inability of neohippocratism to interpret a clinical experience unambiguously. The reason for that state of affairs was to include elements that could not be adjusted to the content of humoralism and were considered to be well proven facts by physicians of the turn of the 18th and 19th c. in the theoretical level of neo-hippocratism. These elements included, for example, knowledge of the role of the nervous system in the control of physiological processes [32], or increasingly convincing observations about the contagious character of epidemic diseases [4]. The hypothesis by Girolamo Fracastoro, who argued that sexually transmitted diseases may be transmitted by the contact of a sick person with a healthy person (therefore the term contagium that he used to define that factor) already in the 16th c., was not the only convincing one to clinicians anymore. Observations of the contagious character of smallpox and typhus were also extensively justified in empirical terms. Medical topography showed that the latter spreads along the routes that marching armies take, occurs only in certain places, and, as opposed to the interpretation by humoralism, is not transmitted by air. A significant accusation against humoralism was also its belief that diseases transform from one to another depending on the individual response of the patient's body. Contrary to the belief, the developing differential diagnosis attempted to distinguish diseases with consistent symptoms, determine their causes, the standard course and their treatment methods based on a repeatable pattern. Advances in pathoanatomy, which resulted in the location of a disease process in individual organs and then in tissues, as well as advances in physiology, where the knowledge unknown to ancient authors was considered, for example knowledge of the role of the heart in the circulatory system, or the role of the brain in the control of emotional and thought processes, all contributed to the challenging of humoralism. In spite of the doubts, the neo-hippocratism doctrine, based on the humoral theory, retained the normative status in many schools of European clinical medicine until the 1840 s, mostly due to the fact that no other new medical theories that were advanced until the end of the 18th c. were able to convince the European academic world since they did not satisfy the cognitive expectations declared by their authors, whereas medical doctrines serving as their expansions proved to be ineffective. That state of affairs was indicated by hospital reports, medical records, and medical statistics.

The reasons why neo-hippocratism was retained in conventional medicine until as late as the middle of the 19th c. may be presented by referring to the three levels of its structure. Due to the framework of the work, this analysis will be synthetic in character. I expounded on these issues in my previous publications [33]. The constitutive level of neo-hippocratism was naturalistic, which oriented both the concept of physiology and pathology in that way. It was derived from homeostasis, which was achieved through the harmonious cooperation between four humours in the human body: blood, phlegm, yellow bile, and black bile. The balance was fluxional and could be disrupted by factors from the natural environment that affected the body. According to the concept, as long as the body was of sufficient capacity, it was able to restore the balance of the humours on its own. However, if the body was too weak to do so (e.g. due to the age of the patient, its malnutrition, influence of too many adverse stimuli simultaneously etc.), the balance (considered to be health) was disrupted and a disease process was initiated. The process varied in terms of its course and was dependent on to which constitution type the patient was classified. Sanguine, melancholic, choleric, or phlegmatic people were supposed to suffer from a disease differently. Even before the disruption to the balance by external factors, their bodies featured a dominance of one of the humours over the others, which was reflected in a different body type, temperament, different predispositions towards some diseases and higher immunity to others [27]. It was thought that the impact of environmental circumstances over a longer period of time could cause the transition of one disease to another; the same went for the situation when the body was weak. According to the above-mentioned concept of pathology, the objective of therapy was not only to fight a particular and physical cause that triggers a specific pathological process with symptoms located in certain organs, but also to cleanse the body of the contamination that disrupts its proper functioning. The aim was to enable the body to restore homeostasis by itself [34]. If the process proved to be ineffective, the disease ended with the death of the patient. The death was considered to be inevitable in severe presentations of diseases, and the natural course of such disease should not be opposed by the physician. The nomothetic level of the neo-hippocratism doctrine was built on the contraria contrariis curantur belief. The cause of the disruption to the body balance specified by the physician, i.e. the indication of what humour became corrupted and what disrupted its proper functioning, was the basis for actions targeted at its purification. At the variational level, specific 
practical recommendations were derived from the above-mentioned assumptions. The first recommendation was to recognise the methods that made it possible to purify the humours from contamination as a basic and prophylactic therapeutic agent. Bloodletting, laxatives and emetics were the most important methods of therapy. Only after the above-mentioned methods were applied, taking agents with a physical effect, mainly multicomponent herbal medicines, was justified. Their dosing and composition were built on a clear recognition of their action. Therapy was always general, i.e. it was supposed to affect the entire body of the patient, and its aim was to standardise the level of the functioning of the body (to increase or decrease it) within the range of the norm. Elements that were not associated with the original structure of the doctrine in question could be introduced in such a general theoretical and practical model, which was based on centuries-old experience with pharmacognosy and a proper combination of medicines with a specific composition and therapeutic options with specific diseases, distinguished on the basis of symptomatic criteria. As the expected results of therapy were achieved in relation to many simple and common diseases, they were considered to justify the theory on the basis of which neo-hippocratism was developed. The practical application of the doctrine was ineffective in more serious diseases (e.g. chronic and epidemic diseases).

However, the decline of neo-hippocratism and its elimination from the European conventional medicine were not associated with low effectiveness of therapy, but with limitations to the interpretation of clinical experience. "Fluidity" of humoralism involved not only its fundamental theoretical categories, but it also implied practice without any models or norms [10]. Neo-hippocratism was based on an individual relation between the physician and patient, on an individual and unrepeatable diagnosis, which changed unpredictably and could not be oriented, as well as on therapy, which was carried out according to those theoretical assumptions. From the beginning of the 19th c. those were considered to be very serious limitations of the doctrine [4]. Therefore, the increase in therapy effectiveness, expected from clinical physicians by the authorities of absolutist countries and patients, was not achievable unless a normative therapeutic doctrine included modeling elements, both in terms of theory and practice. Between 1800 and 1850 , the expansion of the range of clinical experience was made in the Viennese School and the Edinburgh School. The aim was to develop a new normative doctrine, which would be built on a well-documented theory, on the basis of clinical experience. Thus, no significant innovations in therapy were made; at the same time, the number of medications in use was limited by eliminating those that were regarded as ineffective. The Paris clinical school went one step further - new doctrines referring to the anathomopathological theory were developed, while retaining an empirical orientation of a medicine system. However, none of the doctrines introduced an original and coherent concept of physiology and pathology, which could be widely approved in the European academic world, while the application of the doctrines associated with them proved to be ineffective. In that case, the elements introduced in the French clinical standard (such as auscultation, percussion, research on the inflammation of tissues) were included in the European normative system, which was built on humoralism both at the theoretical and practical level.
At the same time (1797-1848), the German clinical medicine experienced a different situation. Numerous members of the academic world decided to replace humoralism with new theories based on deductive reasoning and to introduce therapeutic doctrines associated with them to didactics and clinical practice. Those theories were to meet those requirements of clinicians that humoralism could not, and were supposed to include clinical experience in a system developed a priori, which could be applied to extensive groups of patients. Doctrines developed on the basis of those theories were to be built on therapeutic systems, the effectiveness of which was to result from their development logic rather than the conclusions drawn from documented clinical experience. Those proposals met with criticism from numerous supporters of the existing normative system, who argued that its theoretical and application abilities were not at the end yet, and new medical theories and doctrines were produced too hastily and without a sufficient foundation in clinical practice. However, the development of a new clinical system met with the approval of the authorities in Prussian and some other German Lutheran countries, who gave support to its proponents and introduced it to universities. At the turn of the 18th and 19th c. reinterpretations of theories developed in the second half of the 18th $\mathrm{c}$. in the leading European clinical schools, namely in the Scottish and Viennese, gained the highest recognition in the German conventional medicine. However, they were adopted in Germany in the form of medical doctrines, which admittedly were formulated at those schools but did not gain support of their authors and proponents - Brownism [35] and Mesmerism [4]. Both J. Brown and F.A. Mesmer were considered dissidents in their society. They were accused of building on the system of their native clinical schools in a selective and simplified fashion, while their disease model, as well as their therapy methods, were non-compliant with the clinical methodology based on experience and observations [36]. However, the protagonists of the system did not consider those accusations as relevant because the new system of the German conventional medicine was not supposed to be built on clinical experience, which was generalised with the use of inductive reasoning. Their native idealism, especially Schelling and Hegel [4], advocated their reasoning. German idealism made it possible to formulate medical theories a priori, which were based on different foundations that those recognised by the supporters of the Medical Enlightenment. Their structure included elements of anthropology associated with Lutheranism and their native system of natural science - physics, chemistry and biology (which were not approved in other European countries), which provide a context for a specific approach to physiology and pathology [4]. The transformed influence of the so-called nervous pathology, which was present in the Brown doctrine, was reflected in the German medical doctrines formulated between 1797 and 1830, while between 1797 and 1848 specific conversions of the fluidic concept present in the Mesmer doctrine were reflected. Both doctrines were considered to be evidence of the effect of nonphysical factors on the human body, which had an actual impact and modified the way the body functions, both through the initiation of pathological processes and their treatment and the restoration of the physiological balance of the body. As the doctrines developed during the above-mentioned period did not incorporate elements in their structure that would make it possible to verify them in empirical terms and eliminate them from medical practice after their 
ineffectiveness was proven, they only existed in the German clinical medicine under arbitrary decisions of the directors of individual clinical schools. Therefore, almost one hundred of German universities included numerous theoretical and therapeutic schools where the rejection of the European clinical system deriving from the Medical Enlightenment was the only thing in common. As far as other aspects were concerned, those schools varied in terms of both clinical theory and practice, while their promoted doctrines were not approved by the academic world elsewhere except for Germany. They met with particularly harsh criticism in Austria, in which the academic world rejected both the philosophy on which they were based and their theoretical system (considered to be irrational) and practical system (considered to be ineffective and characterised by high mortality of patients).

In the Western historical and medical literature, almost all new therapeutic doctrines proposed between 1797 and 1848 are detailed in monographs and articles. I compared those doctrines in my 2007 monograph. I also performed an original analysis of some of them in order to demonstrate the individuality of their system and structure from doctrines that were approved in the main modernisation movement of the European clinical medicine, including those approved in the Polish academic world. Building on the literature and my own research, I can conclude that the strategies based on empirical foundations and aimed at the resolution of the crisis in the European conventional medicine were more effective that those that were based on theoretical foundations a priori and deductive reasoning. New therapeutic doctrines, which were developed in the second half of the 19th c. and based on bacteriology, adopted such an implication because they already incorporated the criteria for empirical verification in their structure and were integrated to form a coherent structure of evidence-based medicine A widely accepted clinical methodology enabled doctrines to be spread irrespective of cultural areas in which they were developed; as a result, those doctrines that were verified in empirical terms were worldwide in scope.

\section{REFERENCES}

1. Zembrzuski L. Dzieje kierunków, teorii i doktryn filozoficzno-lekarskich. Warszawa; 1935.

2. Szumowski W. Historia medycyny, Bilikiewicz 7. Editor, Warszawa: Państwowy Zakład Wydawnictw Lekarskich; 1961. p. 300-8.

3. Płonka-Syroka B. Recepcja doktryn medycznych przełomu XVIII I XIX wieku w polskich ośrodkach akademickich w latach 1784-1863. Wrocław: Wydawnictwo Ossolineum; 1990.p. p.5-7.

4. Płonka-Syroka B. Niemiecka medycyna romantyczna. Warszawa: Wydawnictwo DiG; 2007. p. 144-9; 153-4; 242-355; 157; 149-51, 231345 , 299-353; 263-97; 163-72, 193-7; 265-77; 249-53; 249-58; 217-30; $19-120,241-353$

5. Eleftheriadis A. Struktur der Hippokratischen Theorie der Medizin: logische Aufbau und dynamische Entwicklung der Humoralpathologie. Frankfurt am Main; 1990.

6. Płonka-Syroka B. Problem wyboru teorii przez społeczność naukową na przykładzie nauk medycznych. Prace naukowe Wyższej Szkoły Pedagogicznej w Częstochowie. Filozofia i Socjologia. 1995;(4):177-93.

7. Płonka-Syroka B. Medycyna w historii i kulturze. Warszawa: Wydawnictwo DiG; 2016. p. 262-341; 435-42; 348; 342-423.

8. Płonka-Syroka B. Doktryny medyczne nurtu hermetycznego - struktura, geneza, uwarunkowania recepcji w społeczności naukowej. Med Nowożyt. 1992; (Zeszyt wstępny):7-15.

9. Płonka-Syroka B. Międzykulturowa recepcji doktryn medycznych na przykładzie doktryny Johna Browna (1736-1788). Problemy metodologiczne. Kwartalnik Historii Nauki i Techniki. 1993;38(4):3-37.
10. Hess V. Von der semiotischen zur diagnostischen Medizin. Die Entstehung den klinischen Methode, 1750-1850. Husum: Mathiesen Verlag' 1993. p. $15-70$.

11. Lammel H.-U. Nosologische und therapeutische Konzeptionen in der romatischen Medizin. Berlin: Universitäts Verlag; 1986.

12. Amsterdamski S. Między historią a metodą. Spory o racjonalność nauki. Warszawa: Państwowy Instytut Wydawniczy; 1983. p. 32-4; 35-41.

13. Cohen F. Die zweite Erschaffung der Welt. Wie die modern Naturwissenschaft entstand, Frankfurt am Main - New York: Campus Verlag; 2010. p. 24-36, 143-157.

14. Mason S.F. Geschichte der Naturwissenschaft in den Entwicklung ihren Denkweisen. Stuttgart: Kröner Verlag; 1991. p. 178-248; 95-117.

15. Płonka-Syroka B. An overwiev of the Polish school of medical philosophy from the 19th century to today. J Pharm Pharmacol. 2014;25(2):509-26. 81-8.

16. Bucholz G. Die Medizintheorie Claude Bernard;s: ihr philosophischer und wissenschaftlicher Hintergrund. Murken: Altrogge Verlag; 1985.

17. Latour B. The Pasteurization of France. Cambridge; 1993. p. 35-41.

18. Mejor M. Historia naturalna w dziełach polsko-łacińskich poetów humanistycznych. In: Człowiek wobec natury - humanism wobec nauk przyrodniczych. Humanism. Idee, nurty i paradygmaty humanistyczne w kulturze polskiej, vol. 1. Sokolski J. editor, Warszawa: Wydawnictwo Neriton; 2010. p. 55-75.

19. Kuderowicz Z. Filozofia nowożytnej Europy. Warszawa: Państwowe Wydawnictwo Naukowe; 1989. p. 510-42; Miodoński L. Całość jako paradygmat rozumienia świata $\mathrm{w}$ myśli przełomu romantycznego, Wrocław: Oficyna Wydawnicza Arboretum, 2001, p. 178-188.

20. Pfeifer K. Medizin der Goethezeit. Christoph Wilhelm Hufeland und die Heilkunst des 19. Jahrhundert. Köln - Weimar - Wien: Böhlen Verlag; 2000. p. 146-92.

21. Müller-Tam J. Kunst als Gipfel der Wissenschaft. Ästhetische und wissenschaftliche Weltanschauung bei Carl Gustaw Carus, Berlin - New York: De Grutyer Verlah; 1995.

22. Tsouyopoulos N. Andreas Röschlaub und die romantische Medizin, Stuttgart - New York: Fischer Verlag; 1982. p. 153-99.

23. Wiesing U. Kunst oder Wissenschaft? Über den Konzeptionen der Medizin in der deutschen Romantik. Stuttgart - Bad Canstatt: Frommman-Holzbog Verlag; 1995. p. 35-8.

24. Kuhn TS. Tradycja i nowatorstwo w badaniach naukowych. Warszawa: Państwowy Instytut Wydawniczy; 1985. p. 153-61.

25. Miodoński L. Całość jako paradygmat rozumienia świata w myśli przełomu romantycznego. Wrocław: Oficyna Wydawnicza Arboretum; 2001. p. 247-53.

26. Blecker J. Naturhistorische Schule: 1825-1845: ein Beitrag zur Geschichte der klinische Methode in Deutschland, Stuttgart - New York; 1981.

27. Lorenz G. Das Fortleben konkretanschaulichen Denkmuster an den entwickelten "hippokratischen" Theorien. In: Antike Krankenbehandlung in historisch-vergleichenden Sicht. Studien zum konkret-anschaulichen Denken, Heidelberg: Carl Winter Universitätsverlag; 1990. p. 272-34.

28. Płonka-Syroka B. Neohipokratyzm Thomasa Sydenhama jako próba modyfikacji klasycznego standard patologii humoralnej. Analecta. 2016;25(2):39-60

29. Eckle I. Thomas Sydenhm (1624-1689) und seine Krankheitslehre, seine Rezeption durch Boerhaave in Leiden und dessen Schuler in der Ersten Wiener Schule. Berlin: Freie Universität Verlag; 1988. p. 19-42.

30. Płonka-Syroka B. Die Rezeption der medizinischen Lehre von John Brown in der polnischen akademischen Medizin an der Wende vom 18. und 19. Jahrhundert. In: Heilkunde und Heilmittel: zum Erwerb und Transfer von medizinisch-pharmazeutischen Wissen in Europa. Europäische Wissenschaftsbeziehungen, vo. 5, Aachen: Shaker Verlag; 2013. p. 193-206.

31. William Cullen and the eighteenth century medical world, Doig A. editor. Edinburg; 1991

32. Płonka-Syroka B. Wetter und Krankheit: die meteorologischen Beobachtungen an der Universität Wilna in den Jahren 1804 bis 1843 . In: Von Kometen, Windhosen, Hagelschlag und Wetterballons. Beiträge zur Geschichte der Meteorologie. Europäische Wissenschaftsbeziehungen, vol.8, Kästner I., Kiefer J. editors, Aachen: Shaker Verlag; 2014. p. 199-212.

33. Lorenz G. Das Fortleben konkretanschaulichen Denkmuster an den entwickelten "hippokratischen" Theorien. In: Antike Krankenbehandlung in historisch -vergleichenden Sicht. Studien zum konkret-anschaulichen Denken, Heidelberg: Carl Winter Universitätsverlag; 1990. p. 272-80.

34. Eleftheridis A. Struktur der Hippokratischen Theorie der Medizin: logische Aufbau und dynamische Entwicklung der Humoralpathologie, Frankfurt am Main; 1990.

35. Płonka-Syroka B. Mesmeryzm. Od astrologii do bioenergoterapii Wrocław: Oficyna Wydawnicza Arboretum; 2007. 
36. Miodoński L. Filozofia jako podstawa teorii nauk przyrodniczych i medycznych $w$ idealizmie niemieckim (na przykładzie tzw. dynamicznego przyrodoznawstwa). In: B. Płonka-Syroka (ed). Społeczno-ideowe aspekty medycyny i nauk przyrodniczych XVIII-XX wieku. Studia z Dziejów Kultury Medycznej, vol. 5. Wrocław: Oficyna Wydawnicza Arboretum; 2002. p. $85-102$.

\section{Corresponding author}

Prof. dr hab. Bożena Płonka-Syroka

Department of Human Sciences Faculty of Pharmacy

Wroclaw Medical University

211 A Borowska St., 50-556 Wrocław,

tel.: 512279041

E-mail: bozena@plonka-syroka.pl 